\title{
Hypoxia extends lifespan of Brachionus manjavacas (Rotifera)
}

\author{
Terry W. Snell*, Rachel K. Johnston and Brande L. Jones \\ School of Biological Sciences, Georgia Institute of Technology, Atlanta, Georgia, 30332-2230, USA. \\ * Corresponding author: terry.snell@biosci.gatech.edu
}

Received: 04/04/18

Accepted: 19/06/18

\begin{abstract}
Hypoxia extends lifespan of Brachionus manjavacas (Rotifera)

Work by Maria Rosa Miracle's group in 1989 described the adaptation of natural Brachionus plicatilis populations to low oxygen in oxyclines of meromictic lakes. This adaptation was accomplished by slowing metabolism in hypoxia, altering reproductive schedules and extending generation times. Many years later, Miracle's work inspired us to examine whether hypoxia could extend rotifer longevity and reproduction in our study of the biology of aging. In this paper we show that exposure of rotifers to four days of an atmosphere of $1.6 \% \mathrm{O}_{2}$ extended mean lifespan $107 \%$ over controls in normoxia (20.9 $\% \mathrm{O}_{2}$ ), whose mean lifespan was 7.9 days. Alternating days of hypoxia and normoxia also markedly extended rotifer lifespan by $53 \%$. Exposure to $1.6 \% \mathrm{O}_{2}$ hypoxia nearly doubled lifetime reproduction of females ( $24.3 \mathrm{vs} 12.4$ offspring in control). Hypoxia exposure protected rotifers from subsequent oxidative and UV stress, but not starvation, osmotic or heat stress. The 0-4 day age-classes responded best to hypoxia exposure as compared to hypoxia exposure days 4-8 or 8-12. The protective effects of two days of hypoxia exposure persisted through day 6 , then vanished by day 8 . Rotifer diapausing eggs are especially resistant to hypoxia and hatch in atmospheres containing as little as $1.6 \% \mathrm{O}_{2}$ after a one day delay. Our conclusion is that exposure to hypoxia for four days in the youngest age classes extends rotifer longevity and enhances lifetime reproduction. This response has adaptive value in anoxic sediments where most rotifer diapausing eggs are deposited.
\end{abstract}

Key words: hypoxia, rotifers, Brachionus, lifespan

\section{RESUMEN}

\section{La hipoxia alarga la vida media de Brachionus manjavacas (Rotifera)}

En el trabajo realizado por Maria Rosa Miracle y colaboradores en 1989 se describió la adaptación de las poblaciones naturales de Brachionus plicatilis a los bajos niveles de oxígeno propios de las oxiclinas de los lagos meromícticos. Esta adaptación se conseguia al desacelerar el metabolismo en la hipoxia, alterando su programa reproductivo y a los tiempos de generación. Muchos años después, el trabajo de Miracle nos inspiró la idea de examinar si la hipoxia podría aumentar la longevidad y alargar el periodo reproductivo de los rotiferos en nuestros estudios sobre la biología del envejecimiento. En este trabajo mostramos que la exposición de rotíferos a cuatro días en una atmósfera de $1.6 \%$ de $\mathrm{O}_{2}$ alargó la vida media en un $107 \%$ frente los controles en normoxia (20.9\% de $\mathrm{O}_{2}$ ), cuya vida media era de 7.9 días. La alternancia de días de hipoxia y de normoxia también aumentó marcadamente la vida media de los rotiferos, en un $53 \%$. La exposición a la hipoxia (1.6\% de $\mathrm{O}_{2}$ ) casi duplicó la vida media reproductiva de las hembras (24.3 vs 12.4 descendientes en el control). La exposición a la hipoxia protegió a los rotiferos del subsecuente estrés oxidativo y del ocasionado por la radiación ultravioleta, pero no del estrés debido a la inanición, la adversidad osmótica o térmica. Las clases de edad de 0-4 días respondieron mejor a la exposición a la hipoxia en comparación con la exposición a la hipoxia de las de 4-8 u 8-12 días. Los efectos protectores de dos días de exposición a la hipoxia persistieron hasta el día 6 aunque desaparecieron el día 8. Los huevos de diapausa de rotiferos son especialmente resistentes a la hipoxia y eclosionan en atmósferas con niveles tan bajos como $1.6 \%$ de $\mathrm{O}_{2}$ tan sólo con un día de retraso. Nuestra conclusión es que la exposición a la hipoxia durante cuatro días en las clases de edad más jóvenes aumenta la longevidad del rotifero y alarga la etapa reproductiva. Esta respuesta tiene un valor adaptativo en los sedimentos anóxicos en los que se depositan la mayoría de los huevos de diapausa de los rotiferos.

Palabras clave: hipoxia, rotiferos, Brachionus, vida media 


\section{INTRODUCTION}

It is difficult to predict where inspiration for scientific investigations will originate. Moreover, there often is a long lag time between publication of a paper and incorporating its findings into research. An example is a paper that one of us read with keen interest in 1989 by Esparcia, Miracle and Serra describing the adaptation of natural populations of Brachionus plicatilis to low oxygen environments. This species apparently is able to slow its metabolism in hypoxia, altering its reproductive schedule and extending generation times. These authors suggested that this is accomplished by switching to fermentative metabolic pathways, reducing their respiratory oxygen demand. This adaptation allowed B. plicatilis to occupy low oxygen environments in oxyclines of meromictic lakes that were not habitable by other zooplankters. While fascinating, this paper did not immediately indicate how to incorporate this result into our research program.

More than 20 years later, our lab group was investigating the biology of aging using the rotifer B. plicatilis as an experimental model. There has been a resurgence of interest in rotifers as models of aging (Snell, 2014; Snell et al., 2015; Kaneko et al., 2017; Gribble \& Snell, 2018) and we were keen to find means to extend lifespan and healthspan with minimal environmental interventions. We stumbled across an interesting result of lifespan extension by using glycerol as a dietary supplement (Snell \& Johnston, 2014). Observations led us to hypothesize that glycerol supplements caused rotifers to shift their metabolism away from glycolysis toward oxidative phosphorylation. We recalled the metabolic shift associated with hypoxia hypothesized by Esparcia et al. (1989) and wondered whether exposing rotifers to hypoxia might also extend their lifespan. This idea caused us to embark on a series of experiments, the results of which are described in this paper. We examined how hypoxia modifies longevity and reproduction in the rotifer Brachionus manjavacas, how hypoxia treatments protect rotifers from subsequent oxidative and UV stress, what age-classes best respond to hypoxia exposure, and how long the protective effects of hypoxia persist. We also demonstrate that rotifer diapausing eggs are especially resistant to hypoxia and hatch in atmospheres containing as little as $1.6 \% \mathrm{O}_{2}$.

\section{METHODS}

\section{Rotifer Species and Culturing}

We used Brachionus manjavacas (Fontaneto et al., 2007) as experimental animals in this study. $B$. manjavacas was originally collected from Azov Sea and previously known as Brachionus

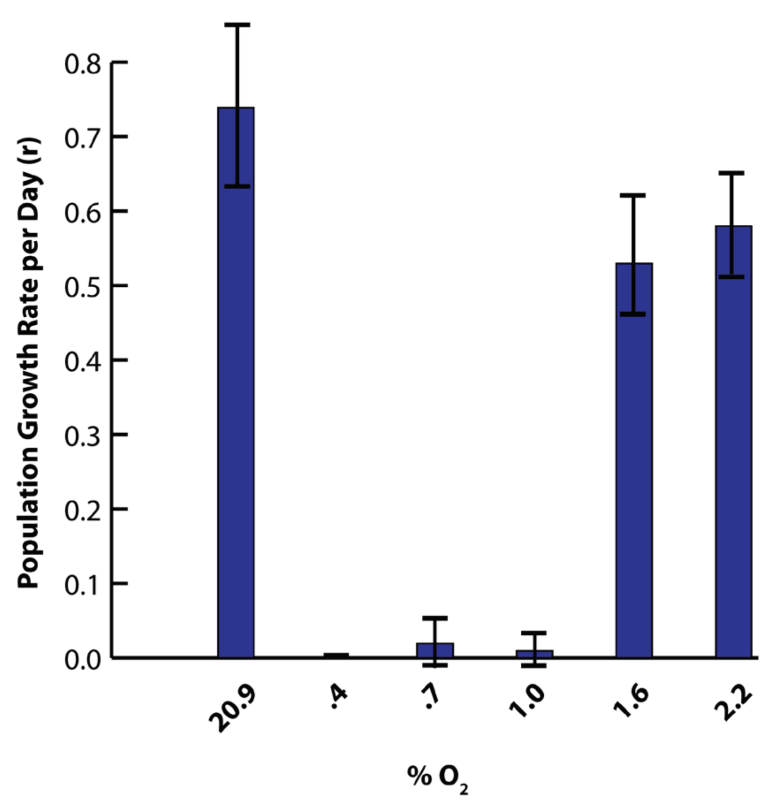

Figure 1. Three-day reproductive assays with varying concentrations of oxygen. B. manjavacas neonates were exposed to 0.4 , $0.7,1.0,1.6$, or $2.2 \% \mathrm{O}_{2}$ for 3 days. $\mathrm{N}=24$ for all five treatments and the control. Percentages represent $\%$ of atmospheric $\mathrm{O}_{2}$ concentration in treatments. The population growth rates (r, offspring per female per day) for each treatment are plotted. Vertical lines indicate standard errors. There were significant decreases in reproduction at $0.4,0.7$ and $1.0 \% \mathrm{O}_{2}$. Population growth rates at $\mathrm{O}_{2}$ concentrations higher than $1.6 \%$ were not significantly different from control. Ensayos de reproducción de tres días variando la concentración de oxígeno. Los neonatos de B. manjavacas fueron sometidos a valores de 0.4, 0.7, 1.0, 1.6 y $2.2 \% \mathrm{O}_{2}$ durante los tres dias. $\mathrm{N}=24$ para los cinco tratamientos y el control. Los porcentajes representan el \% de la concentración de $\mathrm{O}_{2}$ atmosférico en los tratamientos. Se representa la tasa de crecimiento de la población para cada tratamiento $(r$, descendencia por hembra y dia). Las lineas verticales representan el error típico. Hubo descensos significativos en la reproducción a 0.4, 0.7 y $1.0 \%$ de $\mathrm{O}_{2}$. Las tasas de crecimiento poblacional a concentraciones de $\mathrm{O}_{2}$ mayores del $1.6 \%$ no fueron significativamente diferentes del control. 
plicatilis (Snell et al., 2006; Fontaneto et al., 2007). B. manjavacas has been cultured continuously in our laboratory since 1983 (Stout et al., 2010). Rotifers were cultured in 15 ppt artificial seawater (ASW, prepared from Instant Ocean salts) exposed to constant fluorescent illumination (2000 lux) at $25{ }^{\circ} \mathrm{C}$ in all of the following experiments, except if otherwise specified. $B$. manjavacas is a cyclical parthenogen whose life cycle is well understood (Wallace \& Snell 2010).

\section{Oxygen Conditions}

B. manjavacas diapausing eggs were hatched in normoxic culture medium in an atmosphere of $20.9 \% \quad \mathrm{O}_{2}$. Hatchlings, which are asexual females, were transferred to the oxygen treatments within 2 hours of hatching. Desired oxygen concentrations were achieved by flushing a Coy Lab Products anaerobic chamber (approximately $1 \mathrm{~m}^{3}$ volume) with $\mathrm{N}_{2}$ until the desired $\mathrm{O}_{2}$ atmospheric concentrations were reached. This chamber had an oxygen controller, which measured $\mathrm{O}_{2}$ concentrations in air. Because our experimental units were 24-well plates with $1 \mathrm{ml}$ in each well, we assumed that $\mathrm{O}_{2}$ concentration in the medium rapidly came into equilibrium with the $\mathrm{O}_{2}$ concentration in the atmosphere. The small experimental volumes prevented direct measurement of $\mathrm{O}_{2}$ concentration in water using an $\mathrm{O}_{2}$ electrode. The rapidly detectable biological responses in our $\mathrm{O}_{2}$ treatments support this interpretation.

\section{3-Day Reproductive Assays}

Neonates were immediately exposed to $20.9 \%$, $0.1 \%, 0.4 \%, 0.7 \%, 1.0 \%, 1.6 \%$ or $2.2 \% \mathrm{O}_{2}$ atmospheres and fed $2 \times 10^{5}$ Tetraselmis suecica cells $/ \mathrm{ml}$ for 3 days. We recorded the total offspring produced via asexual reproduction during the 3-day period. From these data, instantaneous population growth rate per female per day, r, was calculated as:

$$
\mathrm{r}=\left(\ln \mathrm{Nt}-\ln \mathrm{N}_{0}\right) / \mathrm{T}
$$

where: $\mathrm{Nt}=$ number of rotifers after 3 days, $\mathrm{N}_{0}=$ initial number of rotifers per well (1), and $\mathrm{T}=3$ days.

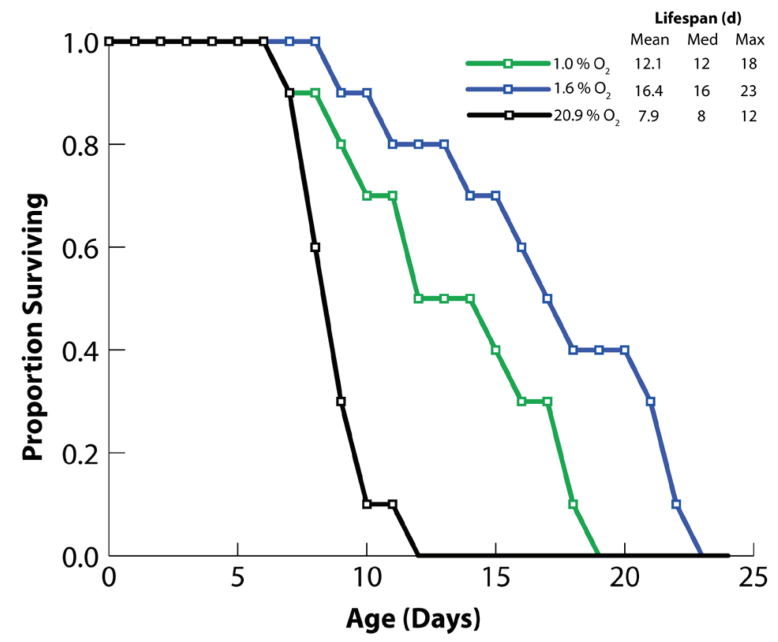

Figure 2. Age-specific survival of B. manjavacas exposed to hypoxic conditions. $B$. manjavacas neonates were continuously exposed to $1.0 \%$ (green), $1.6 \%$ (blue) or $20.9 \%$ (black) $\mathrm{O}_{2}$ over their lifespan. The mean, median and maximum lifespan for each treatment are reported in days. The proportion surviving represents the portion of the initial cohort of 120 females surviving to the indicated age. Treatment with $1.6 \% \mathrm{O}_{2}$ resulted in a significant increase in the lifespan of the females. Supervivencia por edad de B. manjavacas expuesta a condiciones de hipoxia. Neonatos de B. manjavacas fueron expuestos continuamente a $1.0 \%$ (verde), $1.6 \%$ (azul) o $20.9 \%$ (negro) $\mathrm{O}_{2}$ a lo largo de su vida. La media, mediana y máxima esperanza de vida para cada tratamiento esta expresada en días. La proporción de sobrevivientes representa la porción de la cohorte inicial de 120 hembras que sobreviven a la edad indicada. Tratamiento con $1.6 \% \mathrm{O}_{2}$ resultó en un incremento den la esperanza de vida de las hembras.

\section{Life Table Experiments}

Full cohort life tables were performed with 24 female rotifers per treatment. Animals were kept in 24-well plates with 1 female per well in $1 \mathrm{ml}$ medium containing $2 \times 10^{5} \mathrm{~T}$. suecica cells $/ \mathrm{ml}$. Plates were maintained at $22^{\circ} \mathrm{C}$ in the dark in either normoxic conditions or continuous or daily alternating hypoxic conditions of $1.6 \% \mathrm{O}_{2}$. Offspring were counted and removed daily. The original parthenogenetic mothers were transferred to fresh plates on day 6. Plates were monitored daily for mortality until all animals were dead. Data are reported as mean, median and maximum lifespan (age of $95 \%$ mortality). 


\section{Stressor Challenge Experiments}

Rotifers neonates were exposed to $1.6 \% \mathrm{O}_{2}$ for 2 days and fed $6 \times 10^{5}$ T. suecica cells $/ \mathrm{ml}$ with $20 \mu \mathrm{M}$ 5 -fluoro-2'-deoxyuridine (FDU) (Snell et al., 2012) at $25^{\circ} \mathrm{C}$. FDU prevents asexual eggs from hatching, eliminating the challenge of discriminating maternal females from $\mathrm{F} 1 \mathrm{offspring}$. This simplifies experiments and reduces experimental errors. The algae was removed from the medium by filtration. Rotifers were then exposed to stressors, and transferred to fresh ASW for 72-hour recovery, and survival was recorded. The following stressors were applied: (1) $72 \mathrm{~h}$ starvation, (2) $20 \mathrm{~min}$ UV-B exposure, (3) $72 \mathrm{~h}$ oxidative stress, (4) $1 \mathrm{~h}$ osmotic shock, and (5) $1 \mathrm{~h}$ heat shock. UV stress was

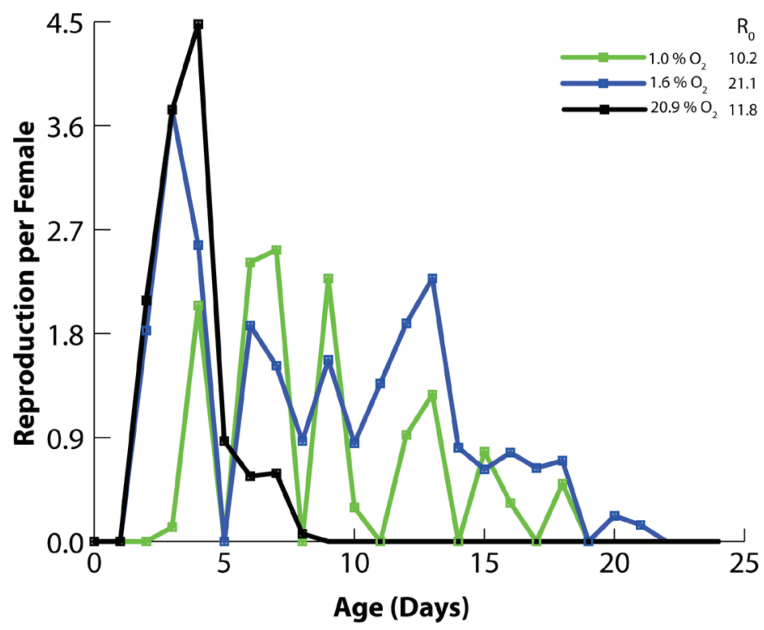

Figure 3. Age-specific reproduction of B. manjavacas exposed to hypoxic conditions. $B$. manjavacas neonates were continuously exposed to $1.0 \%$ (green), $1.6 \%$ (blue) or $20.9 \%$ (black) $\mathrm{O}_{2}$ over their lifespan. Reproduction per female refers to the average daily reproduction by a cohort of 120 females. $R_{0}$ is the mean total reproduction of a female over her lifetime. B. manjavacas neonates were continuously exposed to either $1.0 \%$ (green), $1.6 \%$ (blue) or $20.9 \%$ (black) $\mathrm{O}_{2}$ over their lifespan resulted in a significant increase in lifetime reproduction $\left(\mathrm{R}_{0}\right)$ of the females. Edad específica de reproducción de $\mathrm{B}$. manjavacas expuesta a condiciones hipóxicas. Neonatos de B. manjavacas se expusieron en continuo a $1.0 \%$ de $\mathrm{O}_{2}$ (verde), $1.6 \%$ de $\mathrm{O}_{2}$ (azul), o 20.9\% de $\mathrm{O}_{2}$ (negro) a lo largo de su vida. La reproducción por hembra se refiere a la reproducción diaria promedio de una cohorte de 120 hembras. $R_{0}$ es la reproducción media total de una hembra a lo largo de su vida. La exposición continua de neonatos de B. manjavacas a $1.0 \%$ (verde) y $1.6 \%$ (azul) o a $20.9 \%$ (negro) de $\mathrm{O}_{2}$ a lo largo de su vida resultó en un incremento significativo en la reproducción de las hembras durante el tiempo de vida $\left(R_{0}\right)$. accomplished by exposing the animals to UV-B radiation for $20 \mathrm{~min}, 25 \mathrm{~cm}$ from an $8 \mathrm{~W}$ source (UVP, model UVM-28 EI) with an intensity peak at $302 \mathrm{~nm}$. Rotifers were exposed in $5 \mathrm{ml} \mathrm{ASW}$ in a 55 $\mathrm{mm}$ diameter petri dish so that they received a dose of about $130 \mathrm{~J} / \mathrm{m}^{2}$. Oxidative stress was accomplished by exposing the animals to $0.1 \mu \mathrm{M}$ juglone for 72 hours. Transferring animals from $15 \mathrm{ppt}$ ASW to $60 \mathrm{ppt}$ ASW for 1 hour produced osmotic stress. They were transferred back to $15 \mathrm{ppt}$ ASW and followed for 72 hours. Finally, heat shock was accomplished by transferring the animals from 22 ${ }^{\circ} \mathrm{C}$ to $40{ }^{\circ} \mathrm{C}$ for 1 hour. The animals were transferred to 24 well plates at $25^{\circ} \mathrm{C}$ with $1 \mathrm{ml} 15 \mathrm{ppt}$ ASW, $20 \mu \mathrm{M}$ FDU, and no algae to follow post-stress survival for 72 hours. Each stressor challenge experiment was completed with 12 replicates per treatment, each containing 10 animals.

\section{Retention of Stress Protection}

Retention of oxidative stress protection was examined by exposing neonates to $1.6 \% \mathrm{O}_{2}$ for 2 days, whereas control animals remained at 20.9 $\% \mathrm{O}_{2}$. The hypoxic treated animals were then transferred to normoxic conditions where they were incubated at $25^{\circ} \mathrm{C}$ until removed on days 4 , 6 or 8 to complete oxidative stress tests by exposing the animals to $0.1 \mu \mathrm{M}$ juglone for 72 hours.

\section{Effect of Age of Hypoxia Exposure on Lifespan Extension}

Treating rotifers with hypoxia at different ages tested whether age of exposure alters the protective effects of hypoxia. Animals were transferred from normoxic conditions to $1.6 \% \mathrm{O}_{2}$ for $0-4$ days, 4-8 days or 8-12 days after hatching. The animals then were transferred back to normoxic conditions and followed until death. Full cohort life tables were performed with 120 female rotifers per treatment. Animals were kept in 24-well plates with 5 females per well in $1 \mathrm{ml}$ medium containing $6 \mathrm{x}$ $10^{5}$ T. suecica cells $/ \mathrm{ml}$ in $15 \mathrm{ppt} \mathrm{ASW}$ with $20 \mu \mathrm{M}$ FDU. Plates were maintained at $22^{\circ} \mathrm{C}$ in the dark. All maternal females were transferred to fresh plates on day 6. Plates were monitored daily for mortality until all animals were dead. Data are reported as mean, median and maximum lifespan. 


\section{Diapausing Egg Hatching in Hypoxia}

Four replicate $1 \mathrm{ml}$ wells of $15 \mathrm{ppt}$ ASW containing 100 diapausing eggs were exposed to $20.9 \%$ $\mathrm{O}_{2}$ or $1.6 \% \mathrm{O}_{2}$ at $22{ }^{\circ} \mathrm{C}$ in fluorescent light of 2000 lux. The number hatching was recorded at 24, 48 and $72 \mathrm{~h}$.

\section{Statistics}

Reproductive output and stress challenge tests were analyzed using an ANOVA with Dunnett's test comparing treatments to control. Life table

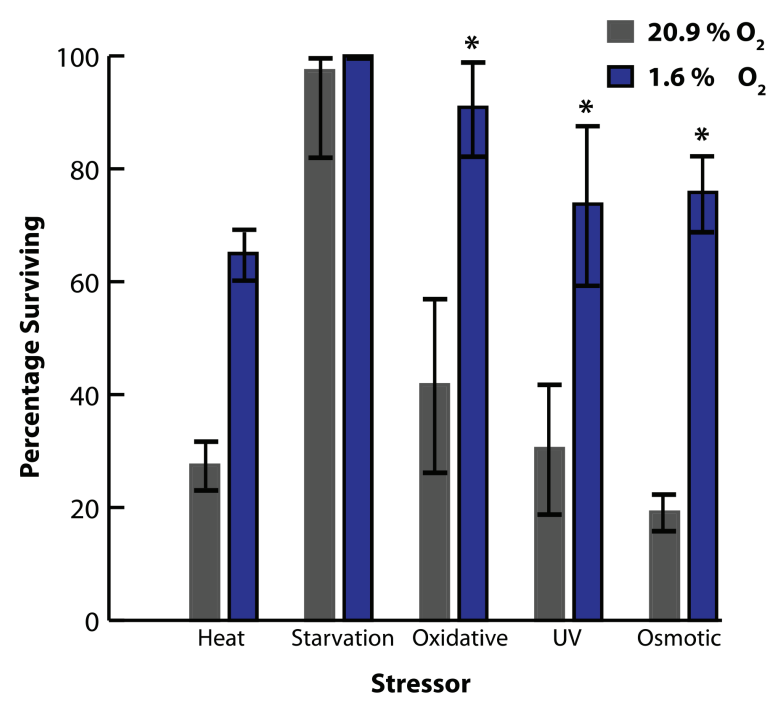

Figure 4. Effect of stressor challenges on B. manjavacas survival. B. manjavacas neonates were exposed to either $20.9 \%$ (control) or $1.6 \% \mathrm{O}_{2}$ (hypoxia) for 2 days, then subjected to the following stressors: starvation, heat, oxidation, osmotic stress, or UV irradiation. Percentages represent $\%$ of atmospheric $\mathrm{O}_{2}$ concentration in treatments. Proportion surviving is the fraction of a cohort of 120 rotifers surviving 48 hours after stressor exposure. Vertical lines indicate standard error. Asterisks indicate significant differences from control by ANOVA and Dunnet's test. Efecto de los desafios estresores sobre la supervivencia de B. manjavacas. Los neonatos fueron expuestos a $20.9 \%$ de $\mathrm{O}_{2}$ (control) o $1.6 \% \mathrm{O}_{2}$ (hipoxia) por 2 dias, y entonces fueron sometidos a los siguientes estresores: inanición, calor, oxidación, estrés osmótico o radiación UV. Los porcentajes representan el \% de la concentración de $\mathrm{O}_{2}$ atmosférico en los tratamientos. La proporción superviviente es la fracción de una cohorte de 120 rotiferos que sobreviven 48 horas después de la exposición al estresor. Las lineas verticales indican error estándar. Los asteriscos indican diferencias significativas respecto al control mediante ANOVA y el test de Dunnet. experiments were analyzed by using the JMP Pro 12 (SAS Institute) reliability and survival analysis with Wilcoxon's test to compare survival curves.

\section{RESULTS}

We screened a range of oxygen concentrations $(0.4 \%-20.9 \%)$ for their effect on B. manjavacas reproduction using a 3-day reproductive test (Fig. 1). The treatments $1.6 \%$ and $2.2 \% \mathrm{O}_{2}$ produced r-values of 0.53 and 0.57 per day, which were not significantly different from the control $(20.9 \%$ $\mathrm{O}_{2}$ ) with an r-value of 0.74 . In contrast, exposure to $\mathrm{O}_{2}$ concentrations $0.4 \%, 0.7 \%$ or $1.0 \%$,

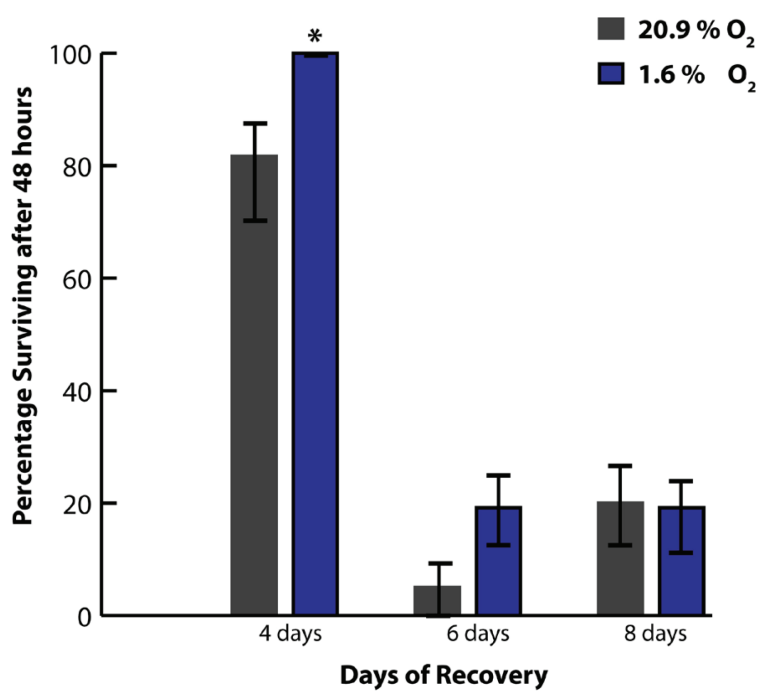

Figure 5. Loss of hypoxia protection. B. manjavacas neonates were exposed to either $20.9 \%$ (control) or $1.6 \% \mathrm{O}_{2}$ (hypoxia) for 2 days. Percentages represent $\%$ of atmospheric $\mathrm{O}_{2}$ concentration in treatments. The females were then transferred to $20.9 \%$ $\mathrm{O}_{2}$ and tested for resistance to oxidative stress $(0.1 \mu \mathrm{M}$ juglone $)$ on days 4,6 , or 8 of their lifespan. Hypoxia exposure provided protection from oxidative stress through day 6 , the protection was lost by day 8 . Vertical lines indicate standard errors and asterisks show significant differences from control by ANOVA and Dunnet's test. Pérdida de la protección de la hipoxia. Neonatos de B. manjavacas se expusieron a $20.9 \%$ de $\mathrm{O}_{2}$ (control) o $1.6 \%$ de $\mathrm{O}_{2}$ (hipoxia) durante dos dias. Las hembras fueron entonces transferidas al $20.9 \%$ de $\mathrm{O}_{2}$ y probadas para su resistencia al estrés oxidativo (0.1 $\mu$ M juglone) los días 4, 6 и 8 de su vida. La exposición a la hipoxia proporcionó protección contra el estrés oxidativo hasta el día 6 , la protección se perdió el día 8. Las líneas verticales indican los errores estándar y los asteriscos muestran diferencias significativas frente al control mediante ANOVA y la prueba de Dunnet. 


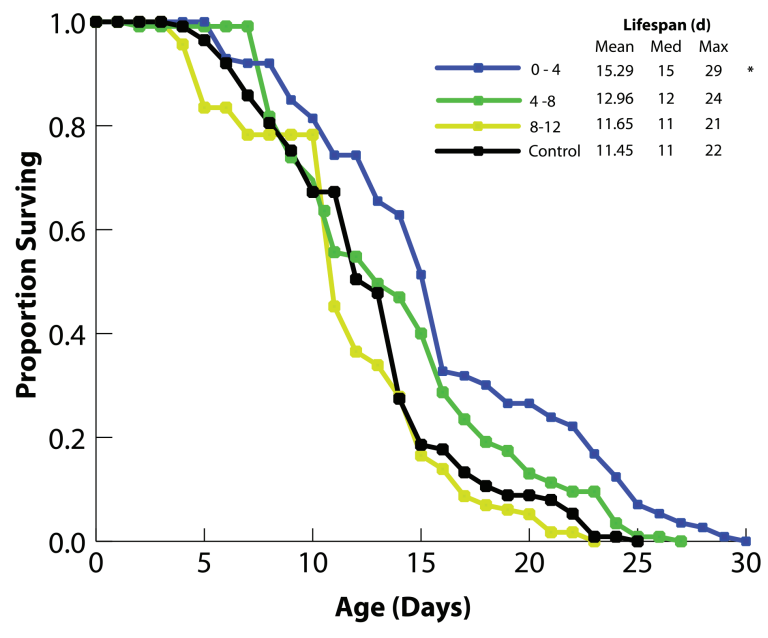

Figure 6. Effect of age of hypoxia exposure on lifespan extension. B. manjavacas neonates were exposed to $1.6 \% \mathrm{O}_{2}$ for different periods throughout their lifespan, either days 0-4 (red), days 4-8 (green) or days 8-12 (blue). Control was continuously exposed to $20.9 \% \mathrm{O}_{2}$. Percentages represent $\%$ of atmospheric $\mathrm{O}_{2}$ concentration in treatments. The rotifers were treated at normoxic $(20.9 \%) \mathrm{O}_{2}$ during the periods before and after hypoxia treatment. The mean, median and maximum lifespan for each treatment are reported in days. The proportion surviving represents the portion of the initial cohort of 120 females surviving to the indicated age. Only treatment from day $0-4$ resulted in a significant increase in their lifespan by Wilcoxson's test of survival curves. Efecto de la edad de la exposición a la hipoxia en el aumento de la esperanza de vida. Neonatos de B. manjavacas fueron expuestos a $1.6 \%$ de $\mathrm{O}_{2}$ en diferentes períodos a lo largo de su vida, los de 0-4 días (rojo), los de 4-8 dias (verde) o los de 8-12 dias (azul). El control fue continuamente expuesto a $20.9 \%$ de $\mathrm{O}_{2}$. Los porcentajes representan el \% de la concentración de $\mathrm{O}_{2}$ atmosférico en los tratamientos. Los rotíferos fueron tratados con normoxicidad (20.9\%) de $\mathrm{O}_{2}$ durante los periodos antes y después del tratamiento de hipoxia. La vida media, mediana y máxima para cada tratamiento se expresaron en días. La proporción de supervivientes representa la porción de la cohorte inicial de 120 hembras que sobreviven a la edad indicada. Solo los del tratamiento de 0-4 días dieron como resultado un aumento significativo en su esperanza de vida.

resulted in at least a 10 -fold decrease in reproductive rate compared to the control in normoxia.

We exposed rotifer females in a cohort life table experiment continuously to $20.9 \%$ or $1.6 \%$ $\mathrm{O}_{2}$ concentrations, or alternating days of normoxia and $1.6 \%$ hypoxia (Fig. 2). Exposure to continuous $1.6 \% \mathrm{O}_{2}$ resulted in a $107 \%$ increase in mean lifespan from 7.9 days in control to 16.4 days in hypoxia. This result was significant with

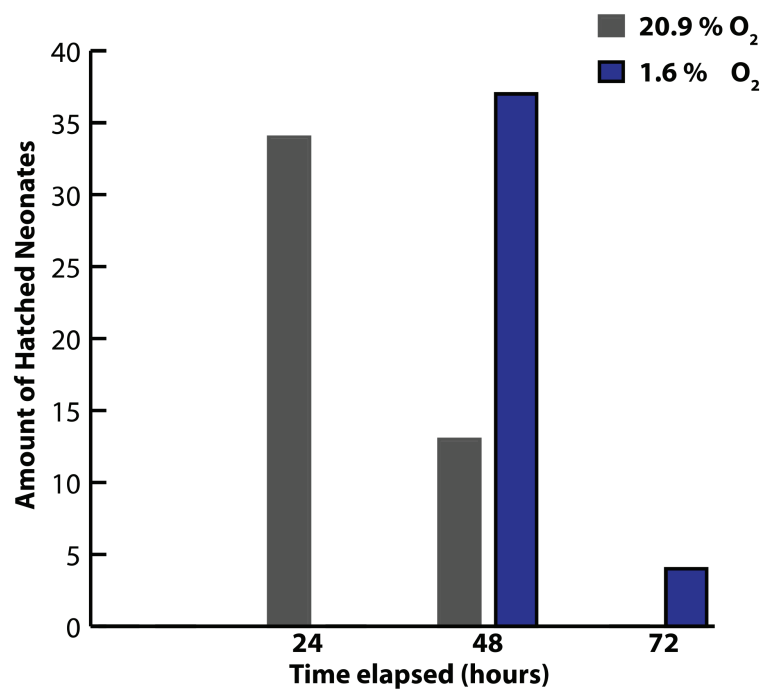

Figure 7. Diapause egg hatching is only delayed in hypoxia. $B$. manjavacas diapausing eggs were hatched in either $20.9 \%$ or $1.6 \% \mathrm{O}_{2}$. Percentages represent $\%$ of atmospheric $\mathrm{O}_{2}$ concentration in treatments. The total number of females hatched was not significantly different, however there was a $24 \mathrm{~h}$ delay in hatching at $1.6 \% \mathrm{O}_{2}$. Vertical lines indicate standard errors. La eclosión del huevo de diapausa solo se retrasa con la hipoxia. Los huevos de diapausa de B. manjavacas se incubaron en 20.9 $\%$ o $1.6 \%$ de $\mathrm{O}_{2}$. Los porcentajes representan el \% de la concentración de $\mathrm{O}_{2}$ atmosférico en los tratamientos. El número total de hembras nacidas no fue significativamente diferente; sin embargo, hubo un retraso de 24 h en la eclosión de los incubados con el $1.6 \%$ de $\mathrm{O}_{2}$. Las líneas verticales indican los errores estándar.

$p<0.001$ by Wilcoxson's test. Mean lifespan likewise significantly increased in the alternating day $1.6 \% \mathrm{O}_{2}$ treatment by $53 \%$ to 12.1 days.

Mean lifetime reproduction $\left(\mathrm{R}_{\mathrm{O}}\right)$ of rotifers exposed to $1.6 \% \mathrm{O}_{2}$ was nearly double that of the control (24.3 vs 12.4 offspring) (Fig. 3). This effect was achieved primarily by higher reproduction in older age classes compared to control. In contrast, there was no significant difference between the alternating day $1.6 \% \mathrm{O}_{2}$ treatment (13.5 offspring) and the control.

Animals exposed to $1.6 \% \mathrm{O}_{2}$ for two days exhibited greater survival than the controls exposed to oxidative or UV stress, but not those exposed to heat, osmotic, or starvation stress (Fig. 4). Pre-treatment of rotifers for two days with 1.6 $\%$ hypoxia increased their survival of oxidative stress by 2.7 -fold. Similar hypoxia exposure improved rotifer resistance to UV exposure by 
4.2-fold. The protective effect of hypoxia was only temporary (Fig. 5), persisting until day 6, but after 8 days the hypoxia protection vanished.

We investigated in which age classes hypoxia exposure provided the greatest lifespan extension. Rotifers were exposed to $1.6 \% \mathrm{O}_{2}$ hypoxia for specific time periods: ages $0-4,4-8$, or $8-12$ days (Fig. 6). For periods not exposed to hypoxia, animals were in $20.9 \% \mathrm{O}_{2}$ normoxia. Only hypoxia treatment from ages 0-4 days resulted in a significant increase in rotifer lifespan.

Exposure of diapausing eggs to hypoxia during hatching delayed their hatching by $24 \mathrm{~h}$ (Fig. 7). Although delayed, a similar fraction of diapausing egg eggs hatched by $72 \mathrm{~h}$ (40 vs $48 \%$ in control).

\section{DISCUSSION}

Our principal findings are that B. manjavacas tolerate severe hypoxia of $1.6 \% \mathrm{O}_{2}$ which is $12 \mathrm{X}$ lower than normal atmospheric $\mathrm{O}_{2}$. Hypoxia exposure extended rotifer lifespan and enhanced lifetime reproduction, primarily by increasing reproduction in older age classes. Pre-exposure of rotifers to hypoxia conferred protection from subsequent oxidative and UV stress, however benefits of hypoxia exposure vanished after $8 \mathrm{~d}$. The benefits of hypoxia exposure were only realized if exposure included the youngest age classes. Rotifer diapausing eggs can hatch in 1.6 $\%$ hypoxia just as well as in normoxia, but are delayed by $24 \mathrm{~h}$.

The first report of high tolerance of hypoxia by species in the $B$. plicatilis species complex was by Esparcia et al. (1989). They found strong rotifer reproduction $\left(r=0.7 \mathrm{~d}^{-1}\right)$ and the maintenance of high population densities (70 rotifers $\mathrm{ml}^{-1}$ ) at $\mathrm{O}_{2}$ concentrations as low as $1 \mathrm{mg} / \mathrm{L}$. Seawater saturates with about $7 \mathrm{mg} \mathrm{O}_{2} / \mathrm{L}$ at 25 ${ }^{\circ} \mathrm{C}$, so $1 \mathrm{mg} / \mathrm{L}$ is about $14 \%$ saturation. This compares with our results with $B$. manjavacas that identified an $\mathrm{O}_{2}$ concentration threshold for vigorous reproduction at about $8 \%$ saturation. Esparcia et al. confirmed that when $\mathrm{O}_{2}$ concentration became anoxic, their population rapidly crashed to extinction, similar to our findings for B. manjavacas. Esparcia et al. also reported that B. plicatilis tolerated hypoxia by lowering its metabolic rate. Hypoxia is a regular feature of many natural rotifer environments, including seasonal oxyclines where surface waters are more oxygenated than the hypolimnion (Miracle \& Vicente, 1983). Since B. manjavacas is adapted to low $\mathrm{O}_{2}$ environments on the edge of anoxic zones, they are pre-adapted to tolerating hypoxia in high-density cultures. This makes them valuable as a larval fish food in aquaculture (Hagiwara et al., 2017).

Hypoxia inducible factor (HIF) proteins have a central role in responding to changes in environmental oxygen (Jiang et al., 2001). HIF proteins are transcription factors stabilized by low-oxygen, modulating the expression of hundreds of genes to produce the hypoxic response (Hochachka \& Lutz, 2001; Ke \& Costa, 2006). Induction of HIF-1 expression in the nematode $C$. elegans increased longevity and healthspan (Zhang et al., 2009; Leiser et al., 2015). So, it is not surprising that exposure to hypoxic conditions had a lifespan extending effect on B. manjavacas.

Ozaki et al. (2010) reported that caloric restriction is prevalent at high population densities in stationary phase of $B$. plicatilis cultures, shifting metabolism from aerobic to anaerobic pathways. These authors speculated that this shift is the mechanism that provides hypoxia tolerance, similar to what was hypothesized by Esparcia et al. (1992).

We conclude that early studies by Maria Rosa Miracle's group demonstrated that brachionid rotifers adapted to hypoxic environments in meromictic lakes. This work foreshadowed how these traits could be exploited in high-density rotifer cultures in marine finfish larviculture and pointed to how hypoxia might be manipulated to extend lifespan and healthspan in rotifer studies on the biology of aging. Like so many of her studies, Maria Rosa's investigation of hypoxia led to much broader influence on rotifer research.

\section{REFERENCES}

ESPARCIA, A., M.R. MIRACLE \& M. SERRA. 1989. Brachionus plicatilis tolerance to low oxygen concentrations, Hydrobiologia, 186/187: 331-337.

ESPARCIA, A., M. SERRA \& M.R. MIRACLE. 
1992. Relationships between oxygen concentration and patterns of energy metabolism in the rotifer Brachionus plicatilis. Comparative Biochemistry and Physiology Part B, 103: 357-362.

FONTANETO, D., I. GIORDANI, G. MELONE \& M. SERRA. 2007. Disentangling the morphological stasis in two rotifer species of the Brachionus plicatilis species complex. Hydrobiologia, 583: 297-307.

GRIBBLE, K.E. \& T.W. SNELL. 2018. Rotifers as a model for the biology of aging. In: Handbook of Models for Human Aging. Elsevier. DOI: 10.1016/B978-0-12-811353-0.00036-1.

HAGIWARA, A., H.J. KIM \& H. MARCIAL. 2017. Mass culture and preservation of Brachionus plicatilis sp. Complex. In: A. Hagiwara, T. Yoshinaga (eds.). Rotifers. Fisheries Science Series, Springer Nature Singapore Pte Ltd. Pp. 35-46. DOI: 10.1007/978981-10-5635-2 1.

HOCHACHKA, P.W. \& P.L. LUTZ. 2001. Mechanism, origin, and evolution of anoxia tolerance in animals. Comparative Biochemistry and Physiology Part B, 130: 435-459.

JIANG H., R. GUO \& J.A. POWELL-COFFMAN. 2001. The Caenorhabditis elegans hif-1 gene encodes a bHLH-PAS protein that is required for adaptation to hypoxia. Proceedings National Academy Sciences U.S.A. 98: 7916-7921.

KANEKO, G. \& T. YOSHINAGA. 2017. Aging and lifespan in the rotifer. In: A. Hagiwara, T. Yoshinaga (eds.), Rotifers: Aquaculture, Ecology, Gerontology, and Ecotoxicology, Springer Nature Singapore, pp. 111-128. DOI: $10.1007 / 978-981-10-5635-21$.

KE Q. \& M. COSTA. 2006. Hypoxia-Inducible Factor-1 (HIF-1). Molecular Pharmacology, 70: 1469-1480.

LEISER S.F., H. MILLER, R. ROSSNER, M. FLETCHER, A. LEONARD, M. PRIMITIVO, N. RINTALA, F.J. RAMOS, D.L. MILLER \& M. KAEBERLEIN. 2015. Cell nonautonomous activation of flavin-contain- ing monooxygenase promotes longevity and health span. Science, 350: 1375-1378.

MIRACLE, M.R. \& E. VICENTE. 1983. Vertical distribution and rotifer concentrations in the chemocline of meromictic lakes. Hydrobiologia, 104: 259-267.

OZAKI, Y, G. KANEKO, Y. YANAGAWA \& S. WATABE. 2010. Calorie restriction in the rotifer Brachionus plicatilis enhances hypoxia tolerance in association with the increased mRNA levels of glycolytic enzymes. Hydrobiologia, 649: 267-277.

SNELL, T.W. 2014. Rotifers as models for the biology of aging. International Review of Hydrobiology, 99(1-2): 84-95.

SNELL, T.W., J.M. KUBANEK, W.E. CARTER, A.B. PAYNE, J. KIM, M. HICKS \& C.P. STELZER. 2006. A protein signal triggers sexual reproduction in Brachionus plicatilis (Rotifera). Marine Biology, 149: 763-773.

SNELL, T.W. \& R.K. JOHNSTON. 2014. Glycerol extends lifespan of Brachionus manjavacas (Rotifera) and protects against stressors. Experimental Gerontology, 57: 47-56.

SNELL, T.W., R.K. JOHNSTON, K.E. GRIBBLE \& D.B. MARK WELCH. 2015. Rotifers as experimental tools to investigate aging. Invertebrate Reproduction \& Development, 59(1): 5-10.

STOUT E.P., J.J. LA CLAIR, T.W. SNELL, T.L. SHEARER \& J. KUBANEK. 2010. Conservation of progesterone hormone function in invertebrate reproduction. Proceedings of the National Academy of Sciences, USA, 107: 11859-11864.

WALLACE, R.L. \& T.W. SNELL. 2010. Rotifera. In: Ecology and Systematics of North American Freshwater Invertebrates. Thorp, J.H. and A.P. Covich (eds.), Academic Press, NY. Third edition.

ZHANG Y., Z. SHAO, Z. ZHAI, C. SHEN \& J.A. POWELL-COFFMAN. 2009 The HIF-1 Hypoxia-Inducible Factor modulates lifespan in C. elegans. PLoS One, 4(7): e6348. DOI: 10.1371/journal.pone.0006348. 